\title{
The Relationship between Iranian EFL Students' Self-efficacy Beliefs and Critical Thinking Ability
}

\author{
Mansoor Fahim \\ Islamic Azad University, Science and Research Branch, Tehran, Iran \\ Alieh Nasrollahi-Mouziraji \\ Islamic Azad University, Science and Research Branch, Tehran, Iran; \\ Department of ELT, Islamic Azad University, Babol Branch, Babol, Mazandaran, Iran
}

\begin{abstract}
The improvement of critical thinking and motivational factors such as self-efficacy seem to have great effects on students' academic achievements. The way in which learners identify their language learning abilities and their ability to control thinking may have a significant impact on their learning outcomes. This study aimed to investigate the relationship between Iranian students' self efficacy and their critical thinking ability. To this end 50 university students majoring in English teaching in Islamic Azad university of Amol and Ghaemshahr branch have been randomly selected to fill out the two questionnaires on Self-efficacy and Critical thinking skills. The finding of the study shows a strong relationship between Iranian students' critical thinking ability and self efficacy. In other words, the higher the students' self efficacy, the higher their critical thinking ability. Generally, the finding provides empirical support that self-efficacy should be considered for developing learners' critical thinking skills.
\end{abstract}

Index Terms—critical thinking ability, self-efficacy, language achievement

\section{INTRODUCTION}

The ability to think is one of the distinguishing features of human beings. We think because we are human. But how do we think? The quality of our thinking is what distinguishes us from other members of our own species. Critical thinking is the cause of our species' improvement and progress. Not every natural thinking process leads to excellence. Hence, Scriven and Paul (2004) suggest its cultivation to prevent it from becoming biased, distorted, partial, uninformed, and prejudiced. That is the reason for recent enthusiasm for the development of critical thinking in education. The field of foreign language education is not an exception. Researchers and teachers in this field are now concerned with identifying the effect of different learner characteristics such as critical thinking abilities and selfefficacy beliefs on learning a foreign/second language.

\section{REVIEW OF RELATED LiterATURE}

\section{A. Critical Thinking}

Many definitions of critical thinking have been proposed up to now. When examined closely, however, they all point to some common principles and criteria. For the purpose of this study Paul, Elder and Bartell's (1997) definition has been adopted. In their definition, they consider critical thinking as "the intellectually disciplined process of actively and skillfully conceptualizing, applying, analyzing, synthesizing, and/or evaluating information gathered from, or generated by, observation, experience, reflection, reasoning, or communication, as a guide to belief and action."(p.4)

As the above definition suggests, at the core of critical thinking are abilities such as analysis, evaluation, interpretation, and making judgment. Pithers and Soden (2000) enumerate the underlying abilities of critical thinking as follows: uncovering assumptions underlying a problem; focusing on the problem; inferencing; inductive and deductive reasoning; and judging the validity and reliability of assumptions and sources of information.

Based on such underlying abilities, the attributes of a critical thinker is summarized by Facione (2011) as follows:

- inquisitiveness with regard to a wide range of issues,

- concern to become and remain well-informed,

- alertness to opportunities to use critical thinking,

- trust in the processes of reasoned inquiry,

- self-confidence in one's own abilities to reason,

- open-mindedness regarding divergent world views,

- flexibility in considering alternatives and opinions 
- understanding of the opinions of other people,

- fair-mindedness in appraising reasoning,

- honesty in facing one's own biases, prejudices, stereotypes, or egocentric tendencies,

- prudence in suspending, making or altering judgments,

- willingness to reconsider and revise views where honest reflection suggests that change is warranted (p.11).

Many writers such as Atkinson (1997) and Fox (1994) argue that CT is embedded in western culture and is incompatible for Asian learners. Other scholars such as Paton (2011) have rejected this idea and speak for the universality of CT. Critical thinking is but one kind of good thinking. It has been equaled by some scholars such as Crombie (1994) to scientific thinking. Despite debate over the definition of critical thinking, it has been acknowledged as a desirable trait that must be embedded in the education system. There is consensus among scholars that education must not only provide learners with the "what" of knowledge, but also with the "how". Pennycook (1994) points to the shift which has occurred in the conceptualization of learning as an ever- evolving process of discovering, questioning, and reformulating hypotheses rather than rote learning. As a result, teaching critical thinking skills have gained attention in educational research. For instance, Glaser's (1941) seminal work reports that training programs can have beneficial effect on different aspect of CT variable. McBride and Bonnette (1995) have also reported that training and education can foster CT in at-risk groups. In his comment on Atkinson's (1997) article, Davidson (1998) maintains that even if critical thinking be considered as a culture-specific trait, the more reason there is for the introduction of critical thinking training. He bases this claim on the idea that "part of the English teacher's task is to prepare learners to interact with native speakers who value explicit comment, intelligent criticism, and intellectual assertion" (p. 121).

\section{B. Self-efficacy}

Learners' perception of their language learning abilities may have a significant impact on their learning outcomes. Cotterall (1999) defines the sense of self-efficacy as "the learners' confidence in their overall ability to learn language"(p. 502). Self-efficacy has emerged as the result of Bandura's social cognitive theory. Bandura (1989) views self-efficacy as a kind of belief held by people about their abilities which helps them to take control over events and tasks. Bandura believes that a person's self-system, which has self-efficacy belief as its essential part, plays a major role in their response to demanding situations.

Self-efficacy is considered as an important source of motivation for people. As Tilfarlioglu and Cinkara (2009, p. 130) state "self-efficacy beliefs regulate human functioning through cognitive, motivational, affective, and decisional processes." That is why it is believed that knowledge is necessary but not sufficient for effective practice. This leads Bandura (1997) to the conclusion that to make effective use of their knowledge, people must also be guided by a kind of self-efficacy belief. Research has shown the enhancing effect of self-efficacy increase on motivation, achievement and confidence. As Linnenbrick and Pintrich (2003) believe, sense of self-efficacy is closely entwined to students' behavioral, cognitive, and motivational engagement and hence learning and achievement. The more self-efficacy learners have, the more they become engaged. Increased engagement leads to better performance. In their 1995 study Ehrman and Oxford (1995) declare that "believing that one can learn languages well was significantly correlated with proficiency in both speaking and reading" (p. 79). In her study, Cotterall (1999) identified six variables leading to autonomy one of which is the self-efficacy beliefs of the learner.

It must be noted that efficacy is not a permanent and steady capability which could be claimed to be present or absent in the learners' inventory of behaviors; rather, as Bandura (1997) maintains, it is "a generative capability in which cognitive, social, emotional and behavioral subskills must be organized and effectively orchestrated to serve innumerable purposes" (pp. 36-37). Pajares (2003, p. 140) identifies interpreted information from four sources which form individuals' self-efficacy perceptions. They include mastery experience (the interpreted result of one's performance), the vicarious experience (the social comparisons made with other individuals), the verbal messages and social persuasions received from others, and physiological states such as anxiety and stress. In the conclusion to his paper, Victori (1992 as cited in Victori \&Lockhart, 1995, p. 225) maintains that if people misconceive their own learning and attribute their achievement in learning to external factors rather than their own action, they will not be able to adopt an active role in their learning and this may be a hindrance to their autonomy.

If self-efficacy is a generative capability and if external factors are so influential in its enhancement, so there must be some strategies to develop such beliefs. Research has proposed several strategies for the purpose, some of which include the use of vicarious and imaginal experiences (Maddux and Lewis, 1995) and controlling physiological and emotional states (Schunk, 1996). Bandura (1997) believes that schools are very great places for the cultivation of selfefficacy beliefs due to some factors such as the presence of peers who provide a good opportunity for modeling and comparison, the presence of teachers who provide essential feedback, modeling and encouragement, along with parental involvement. Pintrich and Schunk (1996) put forward several recommendations to be utilized by teachers with a concern to increase their students' sense of efficacy and achievement:

- Choose materials for which students are competently ready.

- Make students aware of the usefulness of learning in their lives.

- Familiarize students with different learning strategies and make them evaluate the effects of strategy use on their performance. 
- Take individual differences into consideration while presenting the content and make sure that it is understandable for them.

Define learning goals and tell students to keep to them.

- Provide students with as much attributional feedback as necessary.

- Make students aware of their progress and reward them accordingly.

- Use models that build self-efficacy and enhance motivation.

Therefore, it is important to explore how one can enhance self-efficacy among FL learners. Since Glaser's (1941) seminal work, the effect of attitude on CT has been widely acknowledged. Researchers such as Facione, Facione, and Sanchez (1994) maintain that although necessary, mere training does not lead to good critical thinking. Paul and Elder (2001) point to the importance of attitudes or "the characteristics of mind" on CT skills. Different attitudes have been proposed to play a role in this process. The list might include self-regulation, self-confidence, self-esteem, autonomy, and self-efficacy. In Paul, Elder and Bartell's (1997) definition, critical thinking has been considered "as a guide to belief and action"(p.4). It has been concluded that critical thinking and self-efficacy may be related to each other and this study has been conducted, as a result, to prove the claim.

\section{RESEARCH QUESTION}

As it was mentioned earlier, this research was designed to answer the following question regarding the relationship between Iranian students' self efficacy and their critical thinking ability. The research question is:

Is there any relationship between Iranian students' self efficacy and their critical thinking ability?

\section{METHOD}

\section{A. Participants}

50 university students majoring in English teaching have been randomly selected. They were all in their first year of study in Islamic Azad university of Amol and Ghaemshahr branch. Their ages ranged from 19 to 23. The subjects were verbally informed that there was no compulsion in their participation in the study and that it would not influence their grades in the courses.

\section{B. Instruments}

Self-efficacy Questionnaire: Banduras' self-efficacy questionnaire was utilized to measure the self-efficacy of students. It includes 40 items with corresponding 5-piont Likert-scale response options. This questionnaire has been adapted from a survey by Albert Bandura, who has a say in issues related to self-efficacy. Each item expresses certain behavior followed by 5 numbers from which the participants choose the one which best represented their attitude towards the corresponding statement. The Persian version of the questionnaire was validated with 100 university student.

California Critical Thinking Skills Questionnaire: The 34-item California Critical Thinking Skills Test-Form B (CCTST-B-34) was developed to evaluate the critical thinking skills of students. This scale has 34 multi-optional items with only one true answer and integrates 5 critical thinking skills including evaluation, inference, analysis, deductive reasoning and inductive reasoning. The highest score is 34 and the scale must be finished during 45 minutes (Facion $\&$ Facion, 1994). The confident coefficient of the scale according to Khalili et al. (2003) was 0.62 and the construct validity of all subscales was between 0.60-0.65. In this study Kronbach's alpha coefficients was 0.78.

\section{Procedure}

In order to test the hypothesis the subjects were supposed to response the self efficacy questionnaire in 15 minutes. A standardized Persian questionnaire consisting of 40 likert scale items were used in this study. The Persian version was validated with 100 university students from Ferdosi University. Self efficacy scores range from 0-200. For the second variable of the study, critical thinking skills, the students finished the questionnaire within 45 minutes.

\section{Design}

This study is a descriptive one. According to Seliger and Shohamy (1989), this is the kind of research which provides a description of phenomenon in language teaching and processing while it is naturally taking place. The Ex-Post Facto design has been used since the researcher had no control over what has already happened to the participants in the study.

\section{DAta ANAlysis AND Results}

A Pearson correlation is used to find the relationship between self-efficacy and students' critical thinking ability. In order to have a better overview of the variables of the study a descriptive statistics of students' critical thinking and selfefficacy is presented. The following table represents the results of the descriptive statistics for the two instruments, Critical Thinking and Self-efficacy questionnaires. 
TABLE 1

DESCRIPTIVE STATISTICS FOR SELF-EFFICACY AND CRITICAL THINKING

\begin{tabular}{|c|c|c|c|}
\hline & & self efficacy & Critical Thinking \\
\hline \multirow[t]{2}{*}{$\mathrm{N}$} & Valid & 50 & 50 \\
\hline & Missing & 0 & 0 \\
\hline \multicolumn{2}{|c|}{ Mean } & 154.9000 & 24.4000 \\
\hline \multicolumn{2}{|c|}{ Median } & 157.5000 & 25.0000 \\
\hline \multicolumn{2}{|c|}{ Std. Deviation } & 26.95215 & 4.76809 \\
\hline \multicolumn{2}{|c|}{ Variance } & 726.418 & 22.735 \\
\hline \multicolumn{2}{|c|}{ Minimum } & 108.00 & 14.00 \\
\hline \multicolumn{2}{|c|}{ Maximum } & 195.00 & 33.00 \\
\hline
\end{tabular}

In order to find the relationship between the two variables, a Pearson correlation was conducted. As clearly shown in the following table, students' critical thinking ability and self efficacy are strongly correlated.

TABLE 2

PEARSON CORRELATION BETWEEN SELF-EFFICACY AND CRITICAL THINKING OF STUDENTS

\begin{tabular}{|ll|l|l|}
\hline \multicolumn{1}{|c|}{} & Self-efficacy & Critical Thinking \\
\hline self efficacy & Pearson Correlation & 1 & $.761^{* *}$ \\
& Sig.(2-tailed) & .000 \\
& $\mathrm{~N}$ & 50 & 50 \\
\hline Critical Thinking & Pearson Correlation & $.761^{* *}$ & 1 \\
& Sig.(2-tailed) & .000 & 50 \\
$\mathrm{~N}$ & 50 & 5.01 level (2-tailed). \\
\hline
\end{tabular}

The correlation is 0.761 which indicates a strong relationship between the two variables. In fact it can be claimed that there is a positive relationship between self-efficacy and subjects' critical thinking ability. Individuals with higher selfefficacy tend to be better critical thinkers.

\section{CONCLUSION AND IMPLICATIONS}

The present study was carried out to investigate the relationship between self-efficacy beliefs and critical thinking ability in Iranian EFL students. The result of Pearson's correlation coefficient indicates that EFL learners' self-efficacy beliefs have significant effect on their critical thinking levels. In other words, the higher the level of students' selfefficacy, the higher their critical thinking ability. In particular, the results reinforce previous research which indicates a close relationship between critical thinking ability and learners' self-efficacy in learning a second language (Dehghani, et al. 2011; Phan , 2009; Sariolghalam \& Noruzi, 2010). The results lend support to Bandura's (1986) claim made about the influential role of self-efficacy on helpful or debilitating thought patterns and affective reactions. By improving sense of self-efficacy and perceived competence in EFL learners, they would feel more confident, and as a result, more willing to participate critically in class activities. This sense can motivate the learners to take responsibility for their language learning. As Bernat and Gvozdenko (2005, p. 2) state "beliefs are a central construct in every discipline that deals with human behavior and learning." Riley (1996) argues that beliefs will directly shape learner's strategy use and motivation. He claims:

What they [learner] believe will influence their learning much, much more than what we believe, because it is their beliefs that hold sway over their motivations, attitudes and learning procedures. And obviously if there is a misfit between what learners believe and the beliefs embedded in the instructional structure in which they are enrolled, there is bound to be some degree of friction or dysfunction. (p. 152-153)

In the conclusion to her study Cotterall (1995) states that language learners' receptiveness to what has been presented in language classes is affected by their beliefs and if they are not positive, they might act as a kind of hindrance to their success. Low self-efficacy beliefs can demotivate students and hinder their ability to thinking critically. The relationship between self-efficacy, motivation, and achievement is supported in the literature (Bandura, 1986). Studies also show that high level of self-efficacy results in the application of high level learning strategies (Wanga \& Yi Wub, 2008) and can regulate human performances by cognitive and thoughtful processes (Benight \& Bandura, 2004) and the finding of this study supports the assumption that self-efficacy beliefs can influence high level cognitive processes such as critical thinking ability.

\section{REFERENCES}

[1] Atkinson, D. (1997). A Critical approach to critical thinking in TESOL. TESOL Quarterly, 31, 9-37. 
[2] Bandura, A. (1997). Self-efficacy: The exercise of control. New York: Freeman.

[3] Bandura, A. (1986). Social foundations of thought and action: A social cognitive theory. Englewood Cliffs, NJ: Prentice Hall.

[4] Benight, C. \& Bandura, A. (2004). Social cognitive theory of posttraumatic recovery: the role of perceived self-efficacy, Behavior Research and Therapy, 42(10), 1129-1148.

[5] Bernat, E., \& Gvozdenko, I. (2005). Beliefs about language learning: Current knowledge, pedagogical implications, and new research directions. TESL-EJ, $9(1), 1-21$.

[6] Cotterall, L.S. (1995). Readiness for autonomy: Investigating learner beliefs. System, 23(2), 195-205.

[7] Cotterall, L.S. (1999). Key variables in language learning: what do learners believe about them? System, 27, 493-513.

[8] Crombie, A. (1994). Scientific thinking in the European tradition: The history of argument and explanation especially in the mathematical and biological science. Duckworth: London, 3 volumes.

[9] Davidson, B. W. (1998). Comments on Dwight Atkinson's "A critical approach to critical thinking in TESOL": A case for critical thinking in the English language classroom. TESOL Quarterly, 32(1), 119-123.

[10] Dehghani, M., Jafari sani, H., Pakmehr, H., \& Malekzadeh, A. (2011). Relationship between students' critical thinking and selfefficacy beliefs in Ferdowsi University of Mashhad, Iran. Procedia Social and Behavioral Sciences, 15, 2952-2955.

[11] Ehrman, M.E., Oxford, R.L., (1995). Cognition plus: Correlates of language learning success. Modern Language Journal, 79 (1), 67-89.

[12] Facion, P. A., \& Facion, N. C. (1994). The California critical thinking skills test and national. League for nursing accreditation requirement Millbrae, CA: Academic.

[13] Facione, N.C., Facione, P.A., \& Sanchez, C. (1994). Critical thinking disposition as a measure of competent clinical judgment: The development of the California Critical Thinking Disposition Inventory. Journal of Nursing Education, 33 (8), 345-351.

[14] Facione, P. A. (2011). Critical thinking: What it is and why it counts. www.insightassessment.com/content/download/1176/.../what\&why2010.pdf (accessed 29/2/2011).

[15] Fox, H. (1994). Listening to the world. National Council of Teachers of English. Urbana: Illinois.

[16] Glaser, E. M. (1941). An experiment in the development of critical thinking. Teachers College: Columbia University.

[17] Khalili, H, Soleimani, M. (2003). Determining the trust, credibility and norm scores of the California Critical Thinking Skills Test-Form B (TSTCC-B). Journal of Babol University of Medical Sciences, 2, 84-90.

[18] Linnenbrink, E. A., \& Pintrich, P. (2003). The role of self efficacy beliefs in student engagement and learning in the classroom. Reading and Writing Quarterly, 19, 119-137.

[19] MacBride, R., \& Bonnette, R. (1995). Teacher and at-risk students' cognitions during open-ended activities: Structuring the learning environment for critical thinking. Teaching and Teacher Education, 11(4), 373-388

[20] Maddux, J. E., \& Lewis, J. (1995). Self-efficacy and adjustment: Basic principles and issues. In J. M. Maddux (Ed.), Selfefficacy, adaptation and adjustment: Theory, research, and application (pp. 37-68). New York: Plenum Press.

[21] Pajares, F. (2003). Self-efficacy beliefs, motivation, and achievement: A review of the literature. Reading \& Writing Quarterly, 19(1), 139-158.

[22] Paton, M. (2011). Asian students, critical thinking and English as an academic lingua franca. Analytic Teaching and Philosophical Praxis, 32 (1), 27-39.

[23] Paul, R. \& Elder, L. (2001). Critical thinking: Tools for taking charge of your learning and your life. Prentice Hall: New Jersey.

[24] Paul, R., Elder, L., \& Bartell, T. (1997). California teacher preparation for instruction in critical thinking: Research findings and policy recommendations. Dillon Beach, CA: The Foundation for Critical Thinking.

[25] Paul, W. R., \& Elder, L. (2002). Critical thinking: Tools for taking charge of your professional and personal life. New York: Prentice Hall.

[26] Pennycook, A. (1994). Incommensurable discourses? Applied Linguistics, 15 (2), 115-138.

[27] Phan, H. (2009). Relations between goals, self-efficacy, critical thinking and deep processing strategies: a path analysis. Educational Psychology, 29, 777 - 799.

[28] Pintrich, P. R., \& Schunk, D. H. (1996). Motivation in education: Theory, research, and applications. Englewood Cliffs, New Jersey: Prentice-Hall.

[29] Pithers, R. T., \& Soden, R. (2000). Critical thinking in education: A review. Educational Research, 42, 237-249

[30] Riley, P. (1996). "BATs and BALLs": Beliefs about Talk and Beliefs about Language Learning. Proceedings of the International Conference AUTONOMY 2000: the Development of Learning Independence in Language Learning, Bangkok, November, pp. 151-168.

[31] Sariolghalam, N., \& Noruzi, M. (2010). A survey on the relationship between critical thinking and self-efficacy case study: Mathematic students of Payam e Noor University in Maragheh. Studies in Mathematical Sciences, 1(1), 61-66.

[32] Schunk, D. H. (1996). Self-efficacy for learning and performance. Paper presented at the Annual Meeting of the American Research Association. New York, April 1996.

[33] Scriven, M., \& Paul, R. (2004). The Critical thinking community. http://www.criticalthinking.org/aboutCT/definingCT.shtml (accessed 29/2/2011).

[34] Seliger, H. W., \& Shohamy, E. (1989). Second language research methods. Oxford: Oxford University Press.

[35] Tilfarlioglu, F. T., \& Cinkara, E. (2009). Self-efficacy in EFL: Differences among proficiency groups and relationship with success. Novitas-ROYAL, 3(2), 129-142.

[36] Victori, M. \& Lockhart, W. (1995). Enhancing metacognition in self-directed language learning. System, 23(2), $223-234$.

[37] Wanga, S. L., \& Yi Wub, P. (2008). The role of feedback and self-efficacy on web-based learning: The social cognitive perspective. Computers \& Education, 51, 1589-1598. 
Mansoor Fahim was born in Iran in 1946. He received a Ph.D. in TEFL (Teaching English as a Foreign Language) from Islamic Azad University in Tehran, Iran in 1994, an M.A. in General Linguistics from Tehran University in Tehran, Iran in 1978, and a B.A. in English Translation from Allameh Tabataba'i University in Tehran, Iran in 1975.

As for his professional background, he was the chairman of the EFL department at Allameh Tabataba'i University from 2003 to 2007 and a member of the faculty of English Language and Literature at Allameh Tabataba'i University in Tehran, Iran from 1979 to 2008 when he was retired as an associate professor of TEFL. He has also taught English at a welter of universities and language schools. At present, he runs Psycholinguistics, Applied Linguistics, First and Second Language Acquisition, and Discourse Analysis courses at M.A. and Ph.D. levels at a number of universities in Iran, including Allameh Tabatabai and Islamic Azad Universities. Moreover, he has several published articles and books mostly in the field of TEFL.

Dr. Mansoor Fahim is currently a member of the editorial board of the Iranian journal of Applied Linguistic Studies, Sistan \& Baloochestan University, Iran; Journal of Language Studies, Shahrekord University, Iran; and Journal of English Language Studies, Islamic Azad University, Tehran, Iran.

Alieh Nasrollahi-Mouziraji was born in Iran in 1978. She has been a Ph.D. candidate of TEFL (Teaching English as a Foreign Language) at Islamic Azad University in Tehran (Science and Research Branch), Iran since September 2011. She graduated B.A. and M. A. in English literature in Semnan and Shiraz University respectively.

As for her professional background, Nasrollahi has taught English at a number of language schools, and tutored courses in IELTS, TOEFL and FCE since 2003. She has also been a lecturer, running General English and English Grammar courses at Islamic Azad University in Babol, Iran since 2007. Her major research interest in language learning and teaching is in motivational factors, higher level thinking, autonomy and self-regulation. 